\title{
PENINGKATAN HASIL BELAJAR IPS MELALUI MODEL PROJECT BASED LEARNING KELAS IV SDIT AL KAWAAKIB JAKARTA BARAT
}

\author{
Ajat Sudrajat ${ }^{1}$, dan Ika Budiarti ${ }^{2}$ \\ ${ }^{1}$ Universitas Terbuka \\ ${ }^{2}$ SDIT Al Kawaakib Jakarta Barat \\ Email: ajats@ecampus.ut.ac.id
}

\section{Info Artikel}

Sejarah Artikel:

Diserahkan 22 Oktober 2020

Direvisi 15 November 2020

Disetujui 17 November 2020

\section{Keywords:}

learning outcome

social studies

project based learning

\section{Abstract}

The pupose of this study was to increase students attention and learning outcomes on social studies learning content through the project based learning approach in class IV at SDIT Al Kawaakib.

The research subjects were student of class IV with 11 students consist of male 7 students, female 4 students. This research was conducted on february 1 s.d February 29, 2020. Even semester of the 2019/2020 school year.

Based on the results of the study, it shows that student learning outcomes increase with increasing student attention and interes in social studies learning materials through a project-based learning approach. This can be sen from the student learning outcomes in the form of learning completeness which increased up to $73 \%$ at the end of cycle 2. The conclusion of this study shows that the Project Based Learning model can increase interest and learning outcomes of fourth grade students of SDIT Al Kawaakib

\begin{abstract}
Abstrak
Tujuan penelitian ini adalah untuk meningkatkan perhatian dan hasil belajar siswa pada materi pembelajaran IPS melalui pendekatan pembelajaran berbasis proyek pada siswa kelas IV SDIT Al Kawaakib.

Subjek penelitian adalah siswa kelas IV yang berjumlah 11 siswa terdiri dari laki-laki 7 siswa, perempuan 4 siswa. Penelitian ini dilaksanakan pada tanggal 1 Februari s.d 29 Februari 2020. semester genap tahun pelajaran 2019/2020.

Berdasarkan hasil penelitian menunjukkan bahwa hasil belajar siswa meningkat dengan meningkatnya perhatian siswa dan minat pada materi pembelajaran IPS melalui pendekatan pembelajaran berbasis proyek. Hal ini terlihat dari hasil belajar siswa berupa ketuntasan belajar yang meningkat hingga $73 \%$ pada akhir siklus 2 . Kesimpulan penelitian ini menunjukkan bahwa model Pembelajaran Berbasis Proyek dapat meningkatkan minat dan hasil belajar siswa kelas IV SDIT Al Kawaakib
\end{abstract}




\section{PENDAHULUAN}

Ilmu Pengetahuan Sosial (IPS) merupakan suatu program pendidikan yang mengintegrasikan konsep-konsep terpilih dari ilmu-ilmu sosial dan humaniora untuk tujuan pembinaan warga negara yang baik (Samlawi dan Maftuh, 2001). Ruang lingkup IPS mencakup aspek kehidupan manusia di dalam masyarakat, manusia sebagai makhluk sosial. Manusia dalam kehidupannya menyatu dengan alam senantiasa membutuhkan kehadiran sesamanya untuk berinteraksi dan saling membutuhkan. Manusia tinggal di alam sebagai habitat untuk terus melangsungkan kehidupannya seperti di daerah, pesisir, perbukitan dan pegunungan. Pada pelajaran IPS diharapkan siswa mampu memahami permasalahan yang ada di masyarakat serta mensikapi adanya permasalahan tersebut berdasarkan pada pengetahuan yang telah di pelajari.

IPS sebagai salah satu muatan pembelajaran di Sekolah Dasar (SD). Ketertarikan siswa terhadap pembelajaran IPS sering kali rendah. Hal itu dikarenakan karakteristik dari pembelajaran IPS cenderung hafalan. Kesulitan guru juga dirasakan dalam memberikan pembelajaran IPS karena IPS merupakan ilmu yang membutuhkan tingkat kognisi yang cukup tinggi. Sebagian besar materi IPS adalah berupa materi hafalan. Bagi siswa yang memiliki kesulitan dalam menghafal tentu akan merasa tidak nyaman dalam mempelajarinya.

Berdasarkan hasil observasi di kelas IV SDIT Al Kawaakib ditemui bahwa nilai rata-rata yang didapat siswa dari penugasan dan recalling hanya berkisar 72, masih di bawah KKM yang sebesar 75. Jumlah siswa yang berhasil mencapai KKM hanya ada 4 dari total siswa yang berjumlah 11 orang. Hasil observasi diketahui bahwa siswa yang kurang menyukai hafalan, siswa tersebut tidak tertarik terhadap suatu pelajaran sehingga akan sulit untuk memberikan perhatian atau berkonsentrasi dalam mempelajarinya. Secara kasat mata atau melalui pengamatan langsung, siswa yang kurang memiliki minat terhadap suatu pelajaran atau suatu materi tertentu cenderung kehilangan perhatian terhadap guru.

Keberhasilan dari proses pembelajaran tidak terlepas dari penggunaan model pembelajaran yang digunakan oleh guru. Pembelajaran berbasis proyek (Project Based Learning) adalah model pembelajaran yang menggunakan proyek sebagai inti pembelajaran (permendikbud, 2014:20). Model pembelajaran ini merupakan model pembelajaran inovatif yang melibatkan kerja proyek dimana peserta didik bekerja secara mandiri dalam mengkonstruksi pembelajarannya dan mengkulminasikannya dalam produk nyata (Nanang Hanafiah dan $\mathrm{Cucu}$ Suhana, 2009:30).

Project Based Learning (PjBL) memberikan kesempatan pada siswa untuk menentukan sendiri proyek yang akan dikerjakannya baik dalam hal merumuskan pertanyaan yang akan dijawab, memilih topik yang akan diteliti, maupun menentukan kegiatan penelitian yang akan dilakukan. Peran guru dalam pembelajaran adalah sebagai fasilitator, menyediakan bahan dan pengalaman bekerja, mendorong siswa berdiskusi dan memecahkan masalah, dan memastikan siswa tetap bersemangat selama mereka melaksanakan proyek. Pratiwi, dkk (2018) mengungkapkan bahwa $P j B L$ sebagai model pembelajaran yang meminta siswa untuk menyelesaikan sebuah proyek untuk menghasilkan sebuah produk. Sehingga diharapkan dapat meningkatkan kemampuan kognitif dan dan aktivitas siswa yang pada akhirnya memudahkan pemahaman siswa pada suatu materi sehingga dapat meningkatkan hasil belajar siswa.

Tujuan dalam penelitian ini adalah mengetahui peningkatan hasil belajar IPS siswa melalui penerapan model pembelajaran Project Based Learning di SDIT AL Kawaakib Jakarta Barat.

\section{METODE PENELITIAN}

Penelitian ini merupakan Penelitian Tindakan Kelas (PTK) yang dilakukan di SDIT AL Kawaakib Jakarta Barat. Tahapan dalam penelitian tindakan kelas ini meliputi perencanaan, pelaksanaan tindakan, pengamatan dan refleksi. Penelitian ini menggunakan model spiral yang dikembangkan oleh Kemmis dan Taggart (Subyantoro: 2019), seperti gambar di bawah ini:

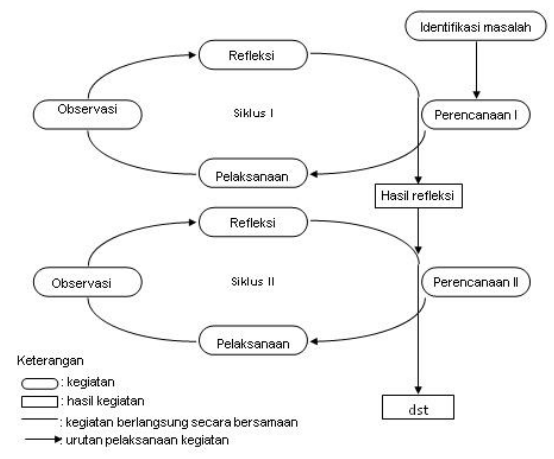

Gambar 1. Model Spiral Penelitian Tindakan Kelas 
Populasi dalam penelitian ini adalah siswa di SDIT AL Kawaakib Jakarta Barat. Sampel dalam penelitian ini, siswa kelas IV SDIT AL Kawaakib Jakarta Barat. Teknik pengambilan data menggunakan observasi dan tes. Instrumen yang digunakan adalah lembar observasi dan lembar tes siswa. Analisis dilakukan secara kualitatif dan kuantitatif.

\section{HASIL DAN PEMBAHASAN}

Penelitian ini dilakukan di SDIT AL Kawaakib Jakarta Barat pada siswa kelas IV. Perolehan data prasiklus, sebelum penerapan model pembelajaran Project Based Learning disajikan dalam Tabel 1 berikut.

\section{Tabel 1. Hasil Kemampuan Siswa Pra Siklus}

\begin{tabular}{cc}
\hline Komponen & Jumlah \\
\hline Jumlah Siswa & 11 \\
Siswa yang sudah tuntas & 4 \\
Siswa yang belum tuntas & 7 \\
Persentase Ketuntasan & $36 \%$ \\
\hline
\end{tabular}

Data tersebut menunjukan bahwa persentase ketuntasan siswa dalam hasil belajar hanya $36 \%$. Ini menunjukan bahwa mayoritas siswa masih belum memahami materi yang disampaikan. Berdasarkan hasil observasi menunjukkan bahwa banyaknya siswa yang tidak memperhatikan saat guru berbicara. Beberapa di antaranya terlihat mengantuk, mengobrol, atau sibuk memainkan benda-benda yang ada di hadapannya. Dari hasil refleksi tersebut, ditarik kesimpulan bahwa perlu adanya model pembelajaran yang membuat siswa banyak bergerak dan mengesplorasi pengetahuan serta bakat mereka. Hasil observasi aktivitas siswa setelah penerapan model pembelajaran Project Based Learning pada siklus I disajikan dalam tabel berikut ini.

Tabel 2: Hasil Observasi Aktivitas Siswa Siklus I

\begin{tabular}{lcc}
\multicolumn{1}{c}{ Aktivitas Siswa } & Jumlah Siswa & Persentase \\
\hline Aktif Bertanya & 5 & $45 \%$ \\
Aktif Menjawab & 5 & $45 \%$ \\
Melaksanakan Arahan & 9 & $82 \%$ \\
Menemukan solusi & 3 & $27 \%$ \\
Mengobrol & 8 & $73 \%$ \\
\hline
\end{tabular}

Berdasarkan tabel di atas, terlihat bahwa keaktifan siswa dalam mengikuti pembelajaran bervariasi. Siswa yang aktif bertanya dan menjawab sekitar $45 \%$. Sebagian besar siswa sebanyak $82 \%$ melaksanakan arahan guru namun dengan kadar kesesuaian dan ketuntasan yang berbeda-beda. Keterlibatan siswa dalam memecahkan masalah dan menemukan solusi hanya berkisar $27 \%$. Sedangkan $73 \%$ siswa masih belum banyak yang fokus.

Pada akhir siklus I dilakukan tes evaluasi untuk mnegukur ketercapaian tujuan pembelajaran. Adapun hasil rekapitulasi kemampuan siswa pada siklus I disajikan dalam tabel berikut ini.

Tabel 3: Rekapitulasi Hasil Kemampuan Siswa Siklus 1

\begin{tabular}{cc}
\hline Komponen & Jumlah \\
\hline Jumlah Siswa & 11 \\
Siswa yang sudah tuntas & 5 \\
Siswa yang belum tuntas & 6 \\
Nilai tertinggi & 87,5 \\
Nilai terendah & 70 \\
Ketuntasan & $45 \%$ \\
\hline
\end{tabular}

Dari tabel di atas, ketuntasan siswa baru berkisar $45 \%$ atau 5 dari 11 siswa. Nilai tertinggi diperoleh 1 siswa dengan skor 87,5. Sedangkan nilai terendah diperoleh 3 siswa dengan skor 70 . Hasil belajar siswa aspek sikap dan keterampilan juga diamati melalui observasi. Hasil observasi penilaian aspek sikap dan keterampilan disajikan dalam Tabel 4 berikut.

Tabel 4: Hasil Penilaian Sikap dan Keterampilan Siklus I

\begin{tabular}{cccc}
\hline \multirow{2}{*}{ Sikap } & Aspek Penilaian & Rata-rata & Kriteria \\
\hline \multirow{2}{*}{ Spiritual } & Perilaku Bersyukur & 2 & Cukup \\
\cline { 2 - 4 } & Berdoa Khusyuk & 2 & Cukup \\
\cline { 2 - 4 } & Jujur & 3 & Baik \\
\cline { 2 - 4 } Sosial & Disiplin & 3 & Baik \\
\cline { 2 - 4 } & Tanggung Jawab & 3 & Baik \\
\cline { 2 - 4 } & Peduli & 3 & Baik \\
\cline { 2 - 4 } & Percaya Diri & 3 & Baik \\
\cline { 2 - 4 } Keterampilan & Pelaksanaan Prosedur & 3 & Cukup \\
\cline { 2 - 4 } & Penggunaan alat dan bahan & 3 & Baik \\
\cline { 2 - 4 } & Keestetisan & 3 & Baik \\
\hline \multirow{3}{*}{ Dari } & hasil penilaian & sikap & serta
\end{tabular}

keterampilan pada tabel di atas menunjukan ratarata capaian nilai cukup hingga baik. Berdasarkan hasil perolehan pada siklus I dilakukan kegiatan refleksi, sehingga dilanjutkan pada siklus II. Hasil observasi aktivitas siswa disajikan dalam tabel berikut ini.

Tabel 5. Hasil Observasi Aktivitas Siswa Siklus II

\begin{tabular}{lcc}
\hline \multicolumn{1}{c}{ Aktivitas Siswa } & Jumlah Siswa & Persentase \\
\hline Aktif Bertanya & 8 & $73 \%$ \\
Aktif Menjawab & 9 & $82 \%$ \\
Melaksanakan Arahan & 11 & $100 \%$ \\
Menemukan solusi & 6 & $55 \%$ \\
Mengobrol & 3 & $27 \%$ \\
\hline
\end{tabular}


Berdasarkan tabel di atas, terlihat peningkatan yang cukup terhadap kualitas aktivitas-aktivitas siswa. Keaktifan siswa dalam bertanya meningkat dari $45 \%$ menjadi $73 \%$ atau dari 5 siswa menjadi 8 siswa. Siswa yang aktif menjawab saat berdiskusi sekitar $82 \%$, meningkat sebanyak 4 siswa dari siklus sebelumnya. Keterlibatan siswa dalam memecahkan masalah dan menemukan solusi meningkat sebanyak 3 siswa. Sedangkan untuk jumlah siswa yang mengobrol terjadi penurunan yang signifikan yaitu dari 8 siswa menjadi 3 siswa.

Pada akhir siklus II dilakukan tes evaluasi untuk melihat peningkatan ketuntasan pembelajaran. Adapun hasil rekapitulasi kemampuan siswa pada siklus I disajikan dalam tabel berikut ini.

Tabel 6: Rekap Hasil Kemampuan Siswa Siklus 2

\begin{tabular}{cc}
\hline Komponen & Jumlah \\
\hline Jumlah Siswa & 11 \\
Siswa yang sudah tuntas & 8 \\
Siswa yang belum tuntas & 3 \\
Nilai tertinggi & 89 \\
Nilai terendah & 70 \\
Ketuntasan & $73 \%$ \\
\hline
\end{tabular}

Ketuntasan siswa meningkat menjadi $73 \%$ atau dari 5 siswa menjadi 8 siswa. Nilai tertinggi sebesar 89 diperoleh 2 siswa, sedangkan nilai terendah diperoleh 3 siswa dengan skor 70. Hasil belajar siswa aspek sikap dan keterampilan pada siklus II juga diamati melalui observasi. Hasil observasi penilaian aspek sikap dan keterampilan pada siklus II disajikan dalam Tabel 7 berikut.

Tabel 7: Hasil Penilaian Sikap dan Keterampilan Siklus II

\begin{tabular}{cccc}
\hline \multirow{2}{*}{ Sikap } & Aspek Penilaian & Rata-rata & Kriteria \\
\hline \multirow{2}{*}{ Spiritual } & Perilaku Bersyukur & 2 & Cukup \\
\cline { 2 - 4 } & Berdoa Khusyuk & 2 & Cukup \\
\hline \multirow{5}{*}{ Sosial } & Jujur & 3 & Baik \\
\cline { 2 - 4 } & Disiplin & 3 & Baik \\
\cline { 2 - 4 } & Tanggung Jawab & 3 & Baik \\
\cline { 2 - 4 } & Peduli & 3 & Baik \\
\hline \multirow{3}{*}{ Keterampilan } & Percaya Diri & 3 & Baik \\
\cline { 2 - 4 } & Keikutsertaan & 2 & Cukup \\
\cline { 2 - 4 } & Pelaksanaan Prosedur & 3 & Baik \\
\cline { 2 - 4 } & Penggunaan alat dan bahan & 3 & Baik \\
\cline { 2 - 4 } & Keestetisan & 3 & Baik \\
\hline
\end{tabular}

Dari hasil penilaian sikap serta keterampilan pada tabel di atas menunjukan peningkatan pada rata-rata capaian semua aspek sudah menunjukan sikap baik.
Sebelum model Project Based Learning pada pembelajaran di terapkan, kemampuan hasil belajar siswa masih tergolong rendah. Pada penelitian pra siklus, guru masih terpusat pada buku dalam penyampaian materi. Siswa terlihat kurang bersemangat, kurang responsif, dan cenderung sibuk sendiri.

Penerapan model pembelajaran Project Based Learning pada siklus I menunjukkan hasil bahwa pembelajaran yang dilakukan belum memberikan hasil yang memuaskan. Oleh karena itu, perlu dilakukan perbaikan pada siklus II. Dalam siklus II ini peneliti mencoba memberikan proyek yang membutuhkan strategi, kerja sama, dan kreativitas tinggi untuk membuatnya. Proyek yang dipilih harus yang benar-benar membuat siswa aktif bergerak, aktif berdiskusi, dan bekerja sama. Sependapat dengan Ardianti, dkk (2017) bahwa pembelajaran dengan model Project Based Learning memberikan pengalaman belajar secara nyata dan langsung melalui kegiatan proyek yang dibuat secara berkelompok. Dengan begitu tidak hanya aspek pengetahuan (kognisi) yang terbangun tetapi juga aspek afeksi dan psikomotor. Dalam proses pembuatan proyek siswa terlatih untuk mengekspresikan ide kreatifnya, melatih sensori motornya serta terbangun sikap sosial dan spiritualnya. Adanya kegiatan merancang proyek maka akan mendukung perkembangan potensi yang ada pada diri masing-masing siswa.

Dari data rekapitulasi terlihat bahwa ratarata nilai siswa mengalami peningkatan dari pra siklus hingga siklus II. Peningkatan rata-rata perolehan hasil belajar siswa dari prasiklus hingga siklus II disajikan dalam gambar berikut.

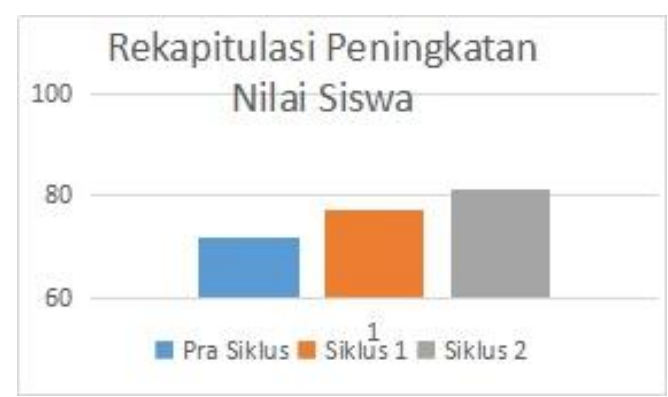

Gambar 2. Grafik Peningkatan Nilai Rata-rata Siswa

Peningkatan hasil belajar siswa dari prasiklus hingga siklus II dikarenakan penerapan model Project Based Learning. Nilai rata-rata siswa dari 72 pada pra siklus, meningkat menjadi 77 pada siklus I, dan 81 pada siklus II. Hutasuhut (2010) berpendapat bahwa project 
Ajat Sudrajat ${ }^{1}$ dan Ika Budiarti ${ }^{2}$

PENINGKATAN HASIL BELAJAR IPS MELALUI MODEL PROJECT BASED LEARNING KELAS IV .... WASIS : Jurnal Ilmiah Pendidikan. Volume 1, Nomor 2, November 2020, hlm. 104-109.

based learning sebagai sebuah model pembelajaran yang dapat melibatkan peserta didik dalam transfer pengetahuan. Sejalan dengan pendapat Titu (2015) bahwa penerapan model project based learning dapat mengajak siswa untuk aktif dalam kegiatan pembelajaran. Hal tersebut menunjukkan bahwa, dengan menggunakan model project based learning, siswa melakukan kegiatan pembelajaran secara aktif dan langsung sehingga akan memberikan dampak yang positif pada peningkatan hasil belajarnya.

Berdasarkan hasil penelitian yang telah dilakukan menggunakan model Project Based Learning (PjBL) siswa kelas IV SDIT Al Kawaakib, maka di dapatkan manfaat dari keunggulan model tersebut yaitu mampu menyelesaikan permasalahan dan tugas secara berkelompok yang akan berdampak pada peningkatan hasil belajar siswa. Utami, dkk (2015) juga menyampaikan bahwa penerapan model Project Based Learning $(P j B L)$ dapat meningkatkan motivasi dan kreativitas siswa pada kegiatan pembelajaran.

Pada kegiatan pembelajaran dengan model Project Based Learning (PjBL) siswa merasa sadar diri memiliki tujuan bersama untuk menyelesaikan tugas secara berkelompok, memiliki tindakan bersama sebagai perwujudan tanggung jawab kelompok, memiliki kemampuan berinteraksi dan berkomunikasi dengan teman, serta bahwa suatu pekerjaan yang diselaikan bersama lebih mudah dan ringan. Siswa juga saling meminta dan memberikan ide, saling membantu dan berpartisipasi menyelasaikan tugasnya, sehingga mampu menghargai hasil yang telah dicapai kelompok.

\section{SIMPULAN}

Berdasarkan penelitian yang telah dilaksanakan terkait penerapan model Project Based Learning pada muatan pembelajaran IPS, maka dapat disimpulkan sebagai berikut: 1) Penerapan model Project Based Learning dapat meningkatkan hasil belajar aspek pengetahuan siswa kelas IV SDIT Al Kawaakib. 2) Hasil belajar dari aspek afektif pun meningkat. Sikap spiritual siswa dalam kegiatan pembelajaran yaitu berdoa serta sikap bersyukur; sikap sosial dalam aktivitas proyek mereka yang membutuhkan sosialisasi atau hubungan dengan sesama; aspek psikomotor pada keterampilan yang diukur berdasarkan keikutsertaan, pelaksanaan prosedur, penggunaan alat dan keestetisan, menunjukan peningkatan yang signifikan.

\section{DAFTAR PUSTAKA}

Ardianti, S.D., Pratiwi, I.A., \& Kanzunnudin, M. (2017). Implementasi Project Based Learning (PjBL) Berpendekatan Science Edutainment Terhadap Kreativitas Peserta Didik. Refleksi Edukatika : Jurnal Ilmiah Kependidikan, 7(2), hlm. 145-150.

Hanafiah, Nanang. dan Cucu, Suhana. 2009. Konsep Strategi Pembelajaran. PT Refika Aditama

Hutasuhut, S. 2010. Implementasi Pembelajaran Berbasis Proyek (Project Based Learning) untuk Meningkatkan Motivasi dan Hasil Belajar Mata Kuliah Pengantar Ekonomi Pembangunan pada Jurusan Manajemen FE Unimed. Pekbis Jurnal. 2(1) 196-207.

Pratiwi, I.A., Ardianti, S.D., \& Kanzunnudin, M. (2018). Peningkatan Kemampuan Kerjasama Melalui Model Project Based Learning (PjBL) Berbantuan Metode Edutainment Pada Mata Pelajaran Ilmu Pengetahuan Sosial. Refleksi Edukatika : Jurnal Ilmiah Kependidikan, 8(2), hlm. 177-182.

Subyantoro.(2019). PTK (Metoda, Kaidah, dan Publikasi). Penerbit: Raja Grafindo Persada.

Titu, MA. 2015. Penerapan Model Pembelajaran Project Based Learning (PjBL) untuk Meningkatkan Kreativitas Siswa Pada Materi Konsep Masalah Ekonomi. Proseding Seminar Nasional 9 Mei 2015.

Utami, R. P., Probosari, R. M., \& Fatmawati, U. M. I. (2015). Pengaruh Model Pembelajaran Project Based Learning Berbantu Instagram Terhadap Kemampuan Berpikir Kreatif Siswa Kelas X SMA Negeri 8 Surakarta. Bio-Pedagogi, 4(1), 4752. 